\title{
Inhibition of the harmful alga Microcystis aeruginosa by sugi (Cryptomeria japonica) bark
}

\author{
Yuri Suzuki ${ }^{1}$, Tomoyuki Johuchi ${ }^{2}$, Hiromi Saijo ${ }^{1,3}$, Koetsu Takahashi ${ }^{1,3}$ and Tatsuya Ashitani ${ }^{1,3^{*}}$ (1)
}

\begin{abstract}
To utilize woody waste for the inhibition of harmful algae, we examined the growth inhibitory activities of sugi (Cryptomeria japonica) bark powder against Microcystis aeruginosa, which is a cyanobacteria species that causes algal blooms in lake or pond areas. The growth of $M$. aeruginosa was inhibited by the direct mixing of sugi bark powder into media in flasks. The inhibitory activity against $M$. aeruginosa was decreased when the bark underwent organic solvent extractions. Thus, the inhibitory activity was promoted by the extract components. After solvent extraction, the bark maintained a level of inhibitory activity suggestive of both chemical and physical effects. These results show that the growth of M. aeruginosa can be suppressed by directly using sugi bark with no extraction treatment.
\end{abstract}

Keywords: Woody wastes, Extract, Algal bloom, Allelopathy, Lake environment

\section{Introduction}

Applications of tree components with allelopathic activities have been studied as methods to suppress algal blooms, which present an environmental problem when caused by harmful algae, such as cyanobacteria species, in lake or pond areas [1, 2]. Nakai et al. [3] reported the inhibition activity of phenolic compounds such as catechin of plant components against the cyanobacterial sp. Microcystis aeruginosa. Tsuchiya et al. [4] studied the inhibitory effects of water extracts from woody plant leaves on $M$. aeruginosa growth, and found that extracts with higher polyphenol contents tended to show higher inhibitory effects. In our recent study [5], bark and heart wood extracts of sugi (Cryptomeria japonica) showed growth inhibitory activities against $M$. aeruginosa. However, there are factors that limit their practical applications, such as extraction costs when using an organic solvent and the environmental risks of using chemicals.

*Correspondence: ashitani@tds1.tr.yamagata-u.ac.jp

${ }^{1}$ Faculty of Agriculture, Yamagata University, 1-23 Wakaba-machi,

Tsuruoka, Yamagata 997-8555, Japan

Full list of author information is available at the end of the article

Part of this report was presented at the $67^{\text {th }}$ Annual Meeting of the Japan

Wood Research Society in Fukuoka, March 2017.
Sugi is a major Japanese forest product and its wood is abundantly used for house building and pulping materials. Sugi bark and wood mill residue, regarded as woody waste products, are generated in large quantities from the wood industry so effective uses for these are required $[6,7]$. Traditionally, sugi logs, as a timber material, were often stored in water in a process known as pond or water storage in Japan, and this method has also been useful in timber production $[8,9]$. Thus, sugi wood and bark materials are considered ecologically safe in a water environment compared with other plant components or chemical reagents. Although the addition of high concentrations of sugi bark extracts to the lake is not practical in terms of impact on other organisms and cost, it is considered relatively safe and cost-effective to use the bark directly without pretreatment. Therefore, we examined the ability of sugi bark powder to inhibit the growth of $M$. aeruginosa to determine the feasibility of its practical applications. The effects of extracted compounds were also examined by comparing the activities of bark samples before and after being subjected to the extraction process. 


\section{Materials and methods}

Extraction and preparation of bark powder

Sugi bark samples from Nagasaki Prefecture were supplied by the Kyushu Regional Agricultural Administration Office of Japan. A section of whole bark was first separated into outer and inner bark, then the bark was cut into fragments of less than $1 \mathrm{~cm}$ using scissors. The bark samples were successively exposed to hexane, ethyl acetate, and methanol to obtain separate extracts. Flavanol contents of ethyl acetate and methanol extracts obtained from whole bark were determined by the vanillin- $\mathrm{HCl}$ method [10] using catechin as a standard. The residual bark after extraction was ground using a Wiley mill to produce the extracted bark powder. Nonextracted bark powder was prepared using a Wiley mill before the extraction process.

Table 1 Yields and growth inhibitory activities of successive extracts obtained from sugi bark

\begin{tabular}{|c|c|c|c|}
\hline & Extraction solvent & Yield $^{\mathrm{a}}(\%)$ & $\begin{array}{l}\text { Inhibitory } \\
\text { activity } \\
(\% \pm S E)\end{array}$ \\
\hline \multirow[t]{3}{*}{ Inner bark } & Hexane & 12.1 & $23.2 \pm 1.09$ \\
\hline & Ethyl acetate & 5.48 & $62.5 \pm 1.08$ \\
\hline & Methanol & 12.4 & $63.2 \pm 0.459$ \\
\hline \multirow[t]{3}{*}{ Outer bark } & Hexane & 5.47 & $48.2 \pm 0.790$ \\
\hline & Ethyl acetate & 1.61 & $38.1 \pm 1.69$ \\
\hline & Methanol & 1.21 & $41.5 \pm 1.85$ \\
\hline \multirow[t]{3}{*}{ Whole bark } & Hexane & 8.42 & $27.6 \pm 1.30$ \\
\hline & Ethyl acetate & 3.14 & $51.7 \pm 0.498$ \\
\hline & Methanol & 5.75 & $50.7 \pm 1.07$ \\
\hline
\end{tabular}

SE standard error

a Yield shows percentage of each extract based on dry weight of bark material

b Bioassay of each extract were conducted at $5 \mathrm{mg} / \mathrm{mL}$ of concentration. Inhibitory activities (IA) were calculated by following equations.

$\mathrm{IA}=100 \times(1$-cell density in each sample test/cell density in control test)

\section{Bioassay}

Bioassays to determine the inhibitory effects of bark extracts against $M$. aeruginosa strain NIES-87 (obtained from the National Institute for Environmental Studies) were performed using $5.0 \mu \mathrm{g} / \mathrm{mL}$ initial extract concentrations in $5 \mathrm{~mL}$ of $M$. aeruginosa medium (MA medium) as described previously [5]. In the assay using bark powder, $M$. aeruginosa was inoculated into $100 \mathrm{~mL}$ of MA medium at ca. $8 \times 10^{5} \mathrm{cell} / \mathrm{mL}$ initial cell density in a 200-mL Erlenmeyer flask. The bark powder was directly mixed at concentrations of 1.0, 5.0, 10, and $50 \mathrm{mg}$ per $100 \mathrm{~mL}$ of medium. The test period was 14 days, and the number of cells was measured with a Thomas hemocytometer every $48 \mathrm{~h}$. The level of growth inhibition was calculated using the inhibition percentage based on the algal growth of the control as described in a previous report [5].

\section{Results and discussion}

\section{Activities of extracts}

The yields and growth inhibitory activities of the successive extracts are shown in Table 1 . The bark sample from Nagasaki prefecture contained high amounts of resin in the inner bark. Yields of bark extracts from this study were much higher than those reported previously [5]. When inner and outer bark were separated from whole bark (non-separated bark), their weights were almost the same, and the yield of each extract from whole bark was an intermediate value between the yields of the respective inner and outer bark extracts. The inhibitory activities of the inner and outer bark extracts were similar to those of a previous report [5]. The activity of each extract obtained from whole bark was intermediate between the activities of the respective inner and outer bark extracts. Ethyl acetate and methanol extracts had higher levels of activity than hexane extract in whole bark as well as inner bark. Active
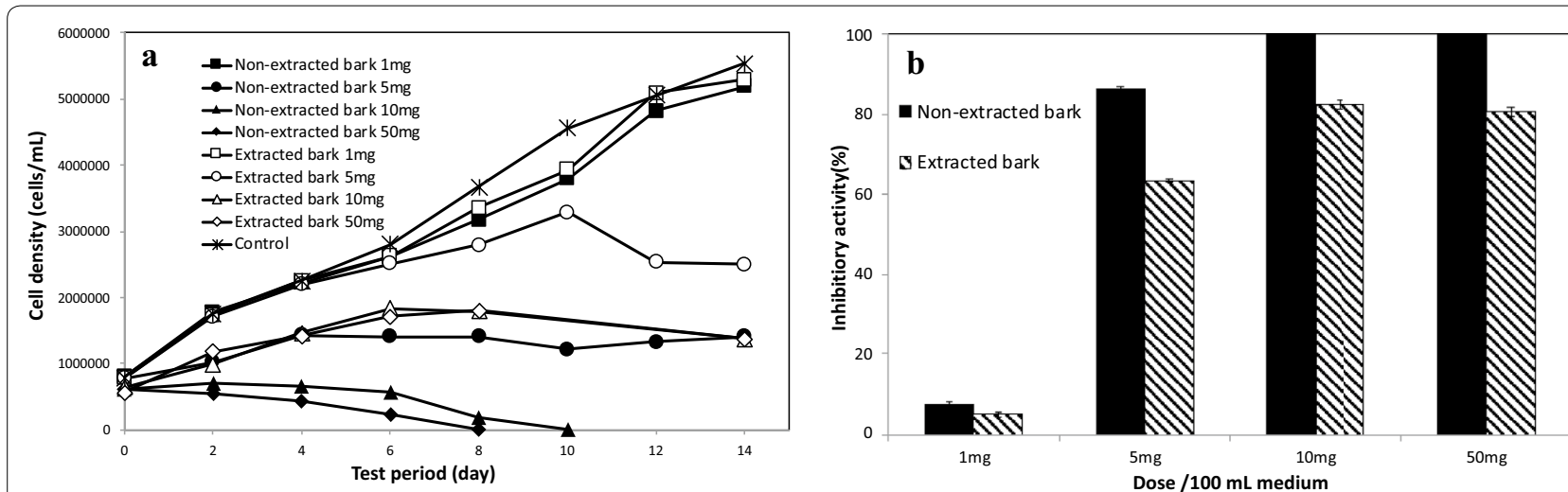

Fig. 1 Growth curve of M. aeruginosa during the 14-day bioassay (a). The inhibitory activity of bark powder compared with control after the bioassay (b). Bar: standard error ( \pm SE) 
compounds in ethyl acetate and methanol extracts of the inner bark were found to be flavanol compounds, as previously indicated [5], constituting $20.3 \%$ and $32.1 \%$ of the extract types, respectively. Flavanol compounds contained in the inner bark were the main active compounds of whole bark extracts.

Table 2 Photographs of culture media at 8 days and 14 days from the start of the bioassay

\begin{tabular}{|c|c|c|c|}
\hline & \multirow{2}{*}{$\begin{array}{l}\text { Bark powder } \\
\text { (Dose/100 mL) }\end{array}$} & \multicolumn{2}{|c|}{ Test Period (day) } \\
\hline & & 8 & 14 \\
\hline \multirow{4}{*}{$\begin{array}{c}\text { Non- } \\
\text { extracted } \\
\text { bark }\end{array}$} & $1 \mathrm{mg}$ & & \\
\hline & $5 \mathrm{mg}$ & & \\
\hline & $10 \mathrm{mg}$ & & \\
\hline & $50 \mathrm{mg}$ & & \\
\hline \multirow{4}{*}{$\begin{array}{c}\text { Extracted } \\
\text { bark }\end{array}$} & $1 \mathrm{mg}$ & & \\
\hline & $5 \mathrm{mg}$ & & \\
\hline & $10 \mathrm{mg}$ & 2 & \\
\hline & $50 \mathrm{mg}$ & & \\
\hline Control & - & & $1:$ \\
\hline
\end{tabular}




\section{Activities of bark powder}

The algal growth curve and the inhibitory activity of bark powder against $M$. aeruginosa during the 14-day testing period are shown in Fig. 1a, b. In media injected independently with $1.0 \mathrm{mg} / 100 \mathrm{~mL}$ of non-extracted and extracted bark powders, the cell density transitions were similar to that of the control, and the inhibitory activity of non-extracted bark was greater than that of extracted bark. The inhibitory activity of the $5 \mathrm{mg} /$ $\mathrm{mL}$ concentration of non-extracted bark was almost the same as that of 10 and $50 \mathrm{mg} / 100 \mathrm{~mL}$ concentrations of extracted bark. Remarkable inhibitory activities against $M$. aeruginosa were observed using non-extracted bark at 50 and $10 \mathrm{mg} / 100 \mathrm{~mL}$ concentrations. The cell density of the medium after the addition of $50-\mathrm{mg} / 100 \mathrm{~mL}$ non-extracted bark powder decreased immediately, and by day 8 , floating algae could not be observed in the medium. Similarly, when $10-\mathrm{mg} / 100 \mathrm{~mL}$ non-extracted bark was added to the medium, the cell density decreased from day 6 to 10, and floating algae could not be observed by day 10 .

Table 2 shows the color change of each culture medium during the test period. Culture media mixed with 10-mg/100 mL non-extracted bark became almost colorless by the end of the test. Thus, the growth of $M$. aeruginosa was inhibited by directly mixing bark powder into the culture medium, although the level of inhibitory activity varied greatly depending on the presence of components extracted by organic solvents. Bark extract components were required for strong inhibitory activity against $M$. aeruginosa; however, extracted bark powder also showed inhibitory activities at high concentrations. In the $50 \mathrm{mg} / 100 \mathrm{~mL}$ concentration test, the culture media of both non-extracted and extracted bark were brown in color (Table 2). We did not perform water extraction of bark samples after organic solvent extraction in this study. Because the color change of the culture media of extracted bark was caused by the water-soluble extract, we speculate that components not extractable by organic solvents, such as highly polar polyphenols, would also have activity. We also observed the adsorption of $M$. aeruginosa cells to the surface of both non-extracted and extracted bark powder microscopically, which suggested that the bark inhibited the growth of $M$. aeruginosa by a physical adsorption effect. This is a topic for future study to clarify the details of the water-soluble extract activity and the physical adsorption effect of sugi bark against $M$. aeruginosa.

\section{Conclusion}

The growth of $M$. aeruginosa was inhibited by the direct mixing of sugi bark powder with culture media. The inhibitory activity was greatly reduced in extracted bark powder, which indicates that the presence of extract components influences inhibitory activity. Because the extracted bark powder maintained an inhibitory activity, components in organic solvent extract residues may also show weak inhibitory activities that could be associated with physical adsorption. This study suggested that the addition of cedar bark directly to a lake or pond area may suppress the growth of $M$. aeruginosa, and proposed a new method of using sugi bark. For practical applications, it will be necessary to carry out safety experiments against other organisms and field tests in the future.

\section{Acknowledgements \\ We thank the staff of the Kyushu Regional Agricultural Administration Office of Japan for supplying bark materials. We also thank Mr. Yukihiro Akehoshi of the Ministry of Agriculture, Forestry and Fisheries of Japan for planning for this study. We thank Lesley Benyon, PhD, and Sarah Williams, PhD, from Edanz Group (www.edanzediting.com/ac) for editing a draft of this manuscript.}

\section{Authors' contributions}

YS, TJ, HS, KT, and TA conceived and designed the experiments. TJ collected sugi bark samples. YS performed the experiments. YS, HS, and TA analyzed experimental data and wrote the manuscript. All authors read and approved the final manuscript.

\section{Funding}

This research was supported by a scholarship from the Kyushu Environmental Evaluation Association.

\section{Availability of data and materials}

All data generated or analyzed during this study are included in this published article.

\section{Competing interests}

The authors declare that they have no competing interests.

\section{Author details}

${ }^{1}$ Faculty of Agriculture, Yamagata University, 1-23 Wakaba-machi, Tsuruoka, Yamagata 997-8555, Japan. ${ }^{2}$ Kyushu Environmental Evaluation Association, 1-10-1 Matsukadai, Higashiku, Fukuoka 813-0004, Japan. ${ }^{3}$ The United Graduate School of Agricultural Science, Iwate University, Morioka 020-8550, Japan.

Received: 12 July 2020 Accepted: 7 October 2020

Published online: 27 October 2020

\section{References}

1. Kessler CT (1988) Effect of juglone on freshwater algal growth. J Chem Ecol 15:2127-2134

2. Yin AQ, Lee HW, Watanabe K, Nakamura K, Park HD, Ban S (2010) Inhibitory effects of Acacia extract on growth of blue-green algae Microcystis spp (in Japanese). Bull Plankton Soc Jpn 57(2):73-78

3. Nakai S, Inoue Y, Lee BD, Hosomi M (2002) Inhibitory effects of plant-produced phenols on algal growth (in Japanese). Jpn J Limnol 63:201-207

4. Tsuchiya R, Kihira M, Sakanoue Y, Araki T (2018) Assessment of inhibition effect on growth of Microcystis aeruginosa by autoclaved water extracts from leaves of 104 woody plant species. Jpn J Limnol 79:41-48

5. Suzuki Y, Saijo H, Takahashi K, Kofujita H, Ashitani T (2018) Growth-inhibitory components in Sugi (Cryptomeria japonica) extracts active against Microcystis aeruginosa. Cogent Environ Sci 4:1466401

6. Ikami Y (2007) Current State and Prospects of Utilization of Wood Residue (in Japanese). Wood Industry 62:50-55

7. Saijo H, Tsuruta K, Kusumoto N, Ashitani T, Takahashi K (2013) Growth inhibition activities of Sugi bark components against Heterosigma akashiwo. J Wood Sci 59(3):238-242 
8. Kobayashi Y, lida I, Imamura Y, Watanabe U (1998) Drying and anatomical characteristics of sugi wood attacked by bacteria during pound storage. J Wood Sci 44:432-437

9. Shida S, Kawai Y, Sadanari M, Tsuchimoto T (2013) Drying rate of Japanese cedar after ten month water storage (in Japanese). Mokuzai Kogyo 68(7):296-300

10. Broadhurst BR, Jones TW (1978) Analysis of condensed tannins using acidified vanillin. J Sci Food Agric 29:788-794

\section{Publisher's Note}

Springer Nature remains neutral with regard to jurisdictional claims in published maps and institutional affiliations.

\section{Submit your manuscript to a SpringerOpen ${ }^{\circ}$ journal and benefit from:}

- Convenient online submission

- Rigorous peer review

- Open access: articles freely available online

- High visibility within the field

- Retaining the copyright to your article

Submit your next manuscript at $\boldsymbol{\nabla}$ springeropen.com 